\title{
Genome-Wide Investigation of 2,4-Diacetylphloroglucinol Protection Genes in Arabidopsis thaliana
}

\author{
Dae-Han Chae, ${ }^{1}$ Da-Ran Kim, ${ }^{2}$ Gyeongjun Cho, ${ }^{1}$ Suhyeon Moon, ${ }^{2}$ and Youn-Sig Kwak ${ }^{1,2,+}$ \\ ${ }^{1}$ Division of Applied Life Science (BK21Plus), Gyeongsang National University, Jinju 52828, Korea \\ ${ }^{2}$ Department of Plant Medicine, Institute of Agriculture \& Life Science, Gyeongsang National University, Jinju 52828, Korea
}

Accepted 4 May 2020.

\begin{abstract}
The compound 2,4-diacetylphloroglucinol (DAPG) is a wellknown secondary metabolite produced by Pseudomonas spp. that are used as biocontrol agents. DAPG displays a remarkably broad spectrum of toxic activity against pathogens of plants. Yet high concentrations of DAPG may also have negative effect on plants, but the phytotoxicity of DAPG is not clearly understood. Here, we used genome-wide activation, tagging Arabidopsis plants as the model plant to investigate the plant response to DAPG. A total of 15 lines were selected as DAPG-tolerant plants from among 62,000 lines investigated. The DAPG-responsible genes were then identified via thermal asymmetric interlaced PCR and quantitative reverse transcription PCR, and the gene ontology analysis showed the distribution of these genes having different biological processes, cellular regulations, and molecular functional properties. Collectively, these findings suggest that plants may rely on several pathways to prevent DAPG phytotoxicity.
\end{abstract}

Keywords: activation-tagging line, biological control, 2,4-diacetylphloroglucinol, genome-wide screening, phytotoxicity

Pseudomonas fluorescens, a soil-inhabitant and gram-negative bacterium, is well known as a biocontrol agent that inhibits plant pathogens (Kwak and Weller 2013; Weller et al. 2007). DAPG (2,4-diacetylphloroglucinol) has several antibiotic properties, such as antifungal, antibacterial, anthelmintic, and even phytotoxic effects (Haas and Keel 2003; Keel et al. 1992; Weller et al. 2007). The pathogen-suppressive activity associated with the production of DAPG reportedly inhibits various plant diseases, such as take-all, damping off, and root rot (Raaijmakers and Weller 2001). While DAPG evidently exhibits toxicity to many plants, its phytotoxic effects upon plants remain largely uninvestigated.

The physiological and biochemical responses of Arabidopsis to $P$. fluorescens FPT9601-T5, a producer of DAPG, were investigated using the microarray approach (Wang et al. 2005).

${ }^{\dagger}$ Corresponding author: Y.-S. Kwak; kwak@gnu.ac.kr

Funding: This research was supported by Basic Science Research Program, through the National Research Foundation of Korea (NRF), funded by the Ministry of Education 2020R1A2C2004177).

*The $\boldsymbol{e}$-Xtra logo stands for "electronic extra" and indicates there are supplementary materials published online.

The author(s) declare no conflict of interest.

๑) 2020 The American Phytopathological Society
Those microarray experiments identified approximately 200 genes that were expressed differently through the DAPGproducer bacterial treatment; particularly so with respect to metabolisms, signal transduction, and detected genes related to stress response. In the rhizosphere, working with a strain overproducing pyoluteorin and DAPG (CHA0/pME3090) Maurhofer et al. (1995) showed that it preserved tobacco roots significantly better than the wild-type strain against Thielaviopsis basicola, but the strain drastically reduced growth of tobacco plants and was toxic to sweet corn. The phytotoxicity of DAPG affects dicotyledonous plants more than monocotyledonous plants (Keel et al. 1992) and it has been hypothesized that DAPG inhibits the root proton secretion system and primary root development (Phillips et al. 2004). In tomato, phytotoxicity of DAPG was also reported (Brazelton et al. 2008), in that DAPG altered the architecture of the tomato root and was capable of interfering with auxin signaling in seedlings. In sum, based on the limited work to date, it seems DAPG activity in plants involves multiple molecular targets that contribute to plant defense as well as phytotoxicity.

To investigate the bioactive mechanism of DAPG, the Saccharomyces cerevisiae genome-wide mutant library has been employed (Kwak et al. 2011; Troppens et al. 2013). That work showed DAPG inhibits fungal growth in several ways, including through damage to the cell membrane, bursts of reactive oxygen, cytosolic acidification, and disturbance to cell homeostasis (Kwak et al. 2011). Another mechanism of DAPG antifungal activity has also been proposed, in which cellularlevel inhibition of respiration and ATP synthesis contributes to growth inhibition as the primary mode of toxicity (Troppens et al. 2013). The above findings suggest that, in a eukaryotic cell, DAPG may act upon several and primary cellular metabolisms.

Despite confirmations of the DAPG mode of action, such results alone are insufficient to establish the plant response at the physiological and cellular levels. To fill this knowledge gap, in this study, the genome-wide activation tagging of Arabidopsis lines was screened to discover genes interacting and plant tolerance to DAPG. Activation tagging of Arabidopsis lines is a powerful tool for genome-wide functional studies of bioactive compounds or other biological factors (Tani et al. 2004; Weigel et al. 2000). Specifically, it relies on multimerized 35S transcription enhancers from the cauliflower mosaic virus that are incorporated by T-DNA into the plant genome, thereby improving the expression of certain genes. The activation-tagging lines are appropriate materials for genome-wide analysis of DAPG-responsible genes to obtain accurate information. The objective of this study was to classify the response of plants to DAPG and to select lines tolerant to DAPG. We hypothesized that i) certain genes in Arabidopsis can regulate DAPG toxicity; 
ii) functional gene overexpression increases plant tolerance to DAPG; iii) the genes involved can be investigated by a genomewide screen with activation-tagged Arabidopsis; and iv) the plant response to DAPG could be predicted by analyzing the gene network and ontology of the Arabidopsis lines selected for tolerance.

\section{RESULTS}

\section{DAPG inhibited the seed germination of Arabidopsis thaliana Col-2.}

Assays for inhibition of the seed germination were evaluated in Murashige Skoog (MS) media with different concentrations of DAPG (Supplementary Fig. S1). In the control, seed rupture was very high, at $99.7 \%$ after 3 days, as was the cotyledon emergence at 6 days $(99.2 \%)$. The percentage of rupture in $40 \mu \mathrm{M}$ DAPG was $9.3 \%$ (6 days), $28.92 \%$ (7 days), $66.6 \%$ (8 days), $75 \%$ (9 days), and $78.9 \%$ (10 days), and cotyledons appeared in $7.8 \%$ ( 7 day), $28.8 \%$ (8 day), $36.8 \%$ (9 day), $72.5 \%$ (10 day) of the samples. The rupture and emergence of cotyledons at concentrations $>60 \mu \mathrm{M}$ DAPG was not observed until 10 days had elapsed (Supplementary Table S1).

\section{A total of $\mathbf{1 5}$ activation-tagging lines showed tolerance against DAPG toxicity.}

The activation-tagging pools were screened for DAPG tolerance, using two steps, and each test result was followed (Supplementary Table S2). The first screening was performed with $50 \mu \mathrm{M}$ DAPG, and this identified a total of 260 lines. The second screening was carried out with the $\mathrm{T}_{4}$ seeds collected from the first screening lines and was conducted with $60 \mu \mathrm{M}$ DAPG, from which 15 lines from the 260 lines were further screened. The seed rupture and germination of the final selected 15 homozygous lines were reconfirmed at 50,60 , and $70 \mu \mathrm{M}$ of DAPG (Fig. 1). In particular, line [15]-1 was the most tolerant of DAPG, having rupture percentages of $58.23 \%$ at $50 \mu \mathrm{M}$, $29.67 \%$ at $60 \mu \mathrm{M}$, and $6.3 \%$ at $70 \mu \mathrm{M}$ in the DAPG-containing MS media.

\section{Phenotype of the selected activation-tagging lines.}

Phenotypic variation was observed in the 16 selected activation-tagging lines, relative to Col-2, at the 15-day growth stage (Supplementary Fig. S2A). On the MS agar medium, the seeds were incubated vertically for 15 days. The primary root length of Col-2 was $52.32 \mathrm{~mm}$, while lines [1]-3 (68.28 mm), [1]-4 (71.48 mm), [1]-7 (65.10 mm), [12]-9 (68.11 mm), [14]-1 (66.15 mm), [15]-1(69.11 mm), [15]-5 (74.96 mm), and [16]-8 $(65.23 \mathrm{~mm})$ all showed longer primary root length than the wild-type (Supplementary Fig. S2B). The Col-2 leaf area was $2.20 \mathrm{~mm}$, which was similar to those of the selected lines (no significant differences were detected [Supplementary Fig. S2C]).

\section{Identification of activation tag-flanking loci in the chromosomes.}

To identify the place of insertion of the 15 selected lines, thermal asymmetric interlaced PCR (TAIL-PCR) amplified the flanking position adjacent to the left border of the pSKI015 vector. Of the $22 \mathrm{AD}$ primers used in the experiment, selected line templates were amplified with eight AD primers (AD1, AD2, AD4, AD9, AD19, AD20, AD21, AD22) (Supplementary Table S3). The PCR conditions used for the primary, secondary, and tertiary TAIL-PCR procedures are outlined in Supplementary Table S4. At each stage, nested PCR products were reduced by a left border primer (LB) designed to have a distance between LB0 and LB1 primers of 54 bp and the distance between LB1 and LB2 primers of $201 \mathrm{bp}$, based on the pSKI015 vector (Supplementary Fig. S3). The tertiary template was eluted from the agarose gel and was sequenced by using the primer LB2. Of the 15 lines tagging Arabidopsis, TAIL-PCR confirmed the flanking loci of 13 lines, but two lines ([9]-4, [9]5) failed to obtain the flanking loci. The TAIR database was searched for the location and direction of the pSKI015 vector in the genome. Figure 2 shows the schematic position of the pSKI015 vector inserted into the exon of the disrupted gene (black box) and intron (white box) regions. Distance is shown as a brown line between LB, right border, and the adjacent gene. Evidently, for some of the lines ([12]-9 and [16]-8) the pSKI015 vector was placed between two genes. For the [12]-9 line, the pSKI015 vector was situated $519 \mathrm{bp}$ to the right of $M C A 1$ and 2,917 bp to the left of the F-box family protein. The [16]-8 line was found positioned $6,969 \mathrm{bp}$ to the right of the transposable element gene and 1,511 bp left of GDSL1. Corresponding physical maps of the insertion position of pSKI015 on chromosome 1 ([1]-3, [1]-4, [1]-11, [15]-5, [16]-8, [16]-10), chromosome 2 ([1]-7, [9]-2), chromosome 3 ([9]-1, [14]-1), chromosome 4 ([1]-8, [12]-9), and chromosome 5 ([15]-1) were drawn (Supplementary Fig. S4).

\section{Expression level of the activated genes.}

Genes that could be activated by the pSKI015 vector were examined in terms of their relative expression level (Fig. 3). The $u b c$ and sand genes served as housekeeping reference genes (Supplementary Table S5) and the predicted genes in the selected lines were compared with the relative level of expression, in terms of fold changes. Among the lines, the gene expression pattern was up-regulated in 12 lines. Representatively, the [16]-10 line coiled-coil protein (CP) expressed 2.251-fold ( $u b c$ gene) and 2.1314-fold (sand gene) higher than the Col-2. The [15]-5 line cell wall-associated kinases (WAKs), overexpressed 3.112-fold ( $u b c$ gene) and 2.842-fold (sand gene) than the wild type. Unexpectedly, in the [16]-8 line, the gene encoding protein of the Gly-Asp-Ser-Leu family of esterases/acylhydrolases (GDSL1, AT1G29670) underwent 0.783 -fold $(u b c)$ and 0.641 -fold (sand) downregulation.

\section{Functional group of DAPG tolerance genes.}

The GeneMANIA network was used to investigate interactions between the 12 genes (Fig. 4). The genes conferring DAPG tolerance in plants showed networked interactions, namely in terms of a physical interaction $(51.91 \%)$, predicted protein interaction $(10.87 \%)$, coexpression $(9.87 \%)$, shared

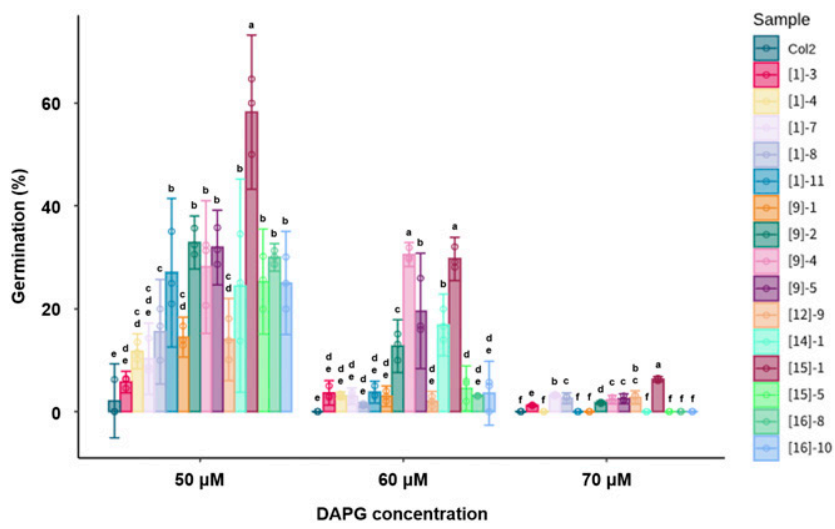

Fig. 1. Seed germination percentages of Arabidopsis thaliana Col-2 and of the selected 15 activation-tagging lines containing 2,4-diacetylphloroglucinol (DAPG) $(50,60,70 \mu \mathrm{M})$ on Murashige Skoog medium. Germination proportions were verified, by seed rupture, at 15 days postincubation. All plants were grown in a growth chamber at $22^{\circ} \mathrm{C}$, under 16 -h light and 8-h dark conditions. Bars with differing letters indicate a significant difference $(P<0.05)$ and error bars represent standard deviations of the means. 
protein $(2.32 \%)$, genetic interaction $(2.22 \%)$, and colocalization $(0.4 \%)$. Nevertheless, four genes (TP, BSDP, FRO5) were left ungrouped from the specified query genes. In the hierarchy of gene functioning with protein domain attributes, Interpro $(22.40 \%)$ identified the coannotation genes. Epidermal growth factor $(E G F)$-like calcium-binding domain (WAKL2, WAKL4, WAKL5, WAKL11, WAKL17, WAKL8, WAK1, WAK3, VSR3, VSR4, WAKL18), zinc finger UBP type (BRIZ1, BRIZ2), ADC synthase (ASA1, ASA2, ICS1, ICS2, ADCS, AT3G55870), hydroxyacylglutathione hydrolase (GLX2-1, GLX2-2, GLX2-4, $G L X 2-5)$, and fatty acid hydroxlase $(S B H 1)$ were included as feature-annotating classes. Based on gene ontology (GO) enrichment, tolerance of DAPG could be linked to the following biological functions: cellular aldehyde metabolic process, thiolester hydrolase activity, organic hydroxyl compound metabolic process (GLX2-1, GLX2-2, GLX2-4, GLX2-5), integral component of plasma membrane (VSR3, VSR4, MCA1), monocarboxylic acid metabolic process (GLX2-1, GLX2-2, $G L X 2-4, G L X 2-5, A D C S$ ), aromatic amino acid family biosynthetic process (ASA1, ASA2, ADCS), establishment of protein localization to vacuole (VSR3, VSR4), tryptophan metabolic process, and tryptophan biosynthetic process (ASAI, ASA2) (Table 1). These results revealed the influence of DAPG phytotoxicity on multiple biological processes in Arabidopsis (Table 2).

\section{DISCUSSION}

DAPG is a well-described bacterial secondary metabolite that is toxic to a wide range of plant pathogens, including many bacteria, fungi, and nematodes (Haas and Keel 2003; Raaijmakers and Weller 2001, 1998). High levels of DAPG are also harmful to plants, inhibiting their growth, and stalling the germination of seeds in a variety of plant species (Keel et al. 1992; Maurhofer et al. 1995). Further, DAPG was also hypothesized to suppress root proton secretion, thus inhibiting primary root growth (Phillips et al. 2004).

We selected the 15 Arabidopsis lines among 62,000 activationtagging pools as DAPG-compliant lines. Adjacent genes of 13 lines were identified, and quantitative reverse transcription PCR

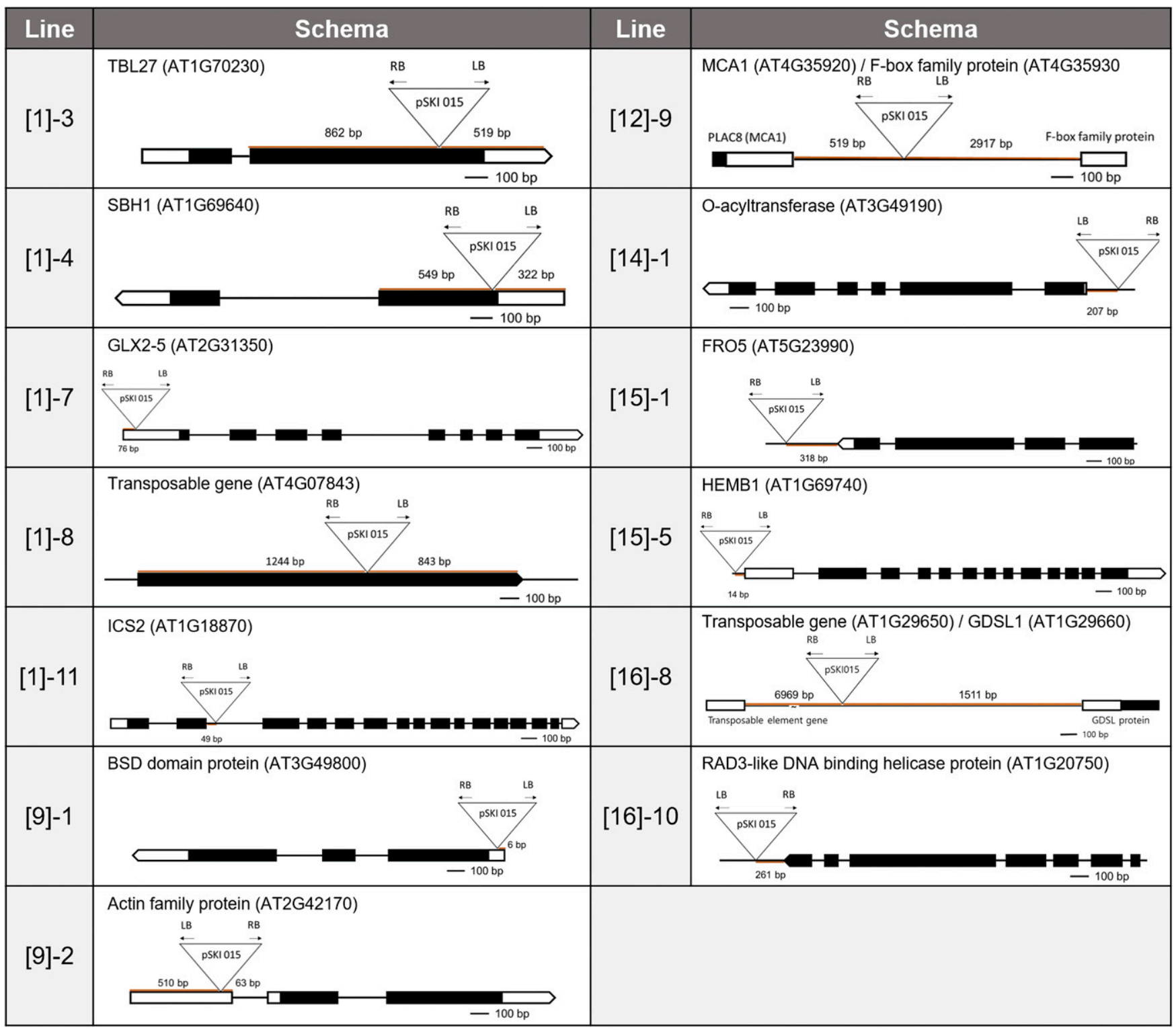

Fig. 2. Schematic representation depicting the insertion of the pSKI015 vector in selected Arabidopsis lines. The triangle is the pSKI015 vector in the flanking positions. Black bars indicate exons, white boxes represent introns, and lines show regions of the untranslated sequences. Each panel is labeled with the gene name and its TAIR ID. $\mathrm{RB}=$ right border and $\mathrm{LB}=$ left border. 
(qRT-PCR) confirmed the expression levels of these genes. GO results suggested that different biological processes, cellular components, and molecular functions that jointly contributed to shaping plant tolerance traits to DAPG. These findings suggest that resistance to DAPG is not just a simple cellular function but, in fact, relies on a complex series of multiple cellular functions. The plasma membrane feature is the cellular interface that governs molecule communication and information shared between cells and their microenvironments (De Marcos Lousa et al. 2012). Integral membrane proteins consist of one or more hydrophobic transmembranes that span the lipid bilayer of the membrane. There are several other ions, hormones, and nutrients transporters that can function as an integral membrane. $\mathrm{ABC}$ transporters are responsible for the efflux or influx of a variety of compounds, including auxins, abscisic acid, and antimicrobials, as a representative example (Schulz et al. 2011). Transporters in membrane (VSR3, VSR4, MCAI) had improved tolerance to DAPG. This result suggested that membrane activity plays a critical and key role in protecting plants against the phytotoxicity posed to them by DAPG.

Genes for reactive oxygen regulation were also selected to improve tolerance to DAPG toxicity in our study. The network interaction map showed DAPG tolerance linked to aldehyde metabolism and thioester hydrolase (GLX2-1, GLX2-2, GLX2$4, G L X 2-5)$. Aldehydes are compounds that are toxic to many organisms (LoPachin and Gavin 2014). The aldehydes were produced in plants when the latter were subjected to abiotic stress, and aldehyde dehydrogenases $(A L D H)$ are known to play an important role in processes of detoxification (Kotchoni et al. 2006). Reduction in $\mathrm{H}_{2} \mathrm{O}_{2}$ and malondialdehyde (MDA) derived from cellular lipid peroxidation was followed by stress tolerance in the $A L D H 3 I 1$-transgenic plant. That finding suggested that $A L D H 3 I 1$ acts not only as an aldehyde-detoxifying enzyme but also as efficient reactive oxygen species (ROS) scavenger, and the enzyme could prevent lipid peroxidation. Thioester hydrolases or thioesterases (TEs) form a large group of enzymes, which hydrolyze the thioester bond between a carbonyl group and a sulfur atom. For fatty acyl-acyl carrier protein TEs (CpFATB), work has shown that constitutive expression by these enzymes activates an oxidative signal cascade and contributes to the regulation of peroxisomes levels (Zhang et al. 2012)

Plant tolerance to DAPG also improved in the Arabidopsis lines characterized by overexpression of amino acids biosynthesis. The aromatic amino acids (AAA) are the key molecules functioning in plant metabolism and their synthesis depends on the common precursor metabolite chorismate, of the shikimate pathway (Tzin and Galili 2010). The AAA also function as precursors of vital plant hormones, such as auxin and salicylate (Bartel 1997; Vogt et al. 2010). In this study, we established the biosynthetic process of the aromatic amino acid family (ASA1, ASA2, ADCS) in the DAPG-tolerance network. Likewise, the biosynthesis pathway for tryptophan is involved in the metabolism of indole-3-acetic acid (auxin), which is catalyzed from indole-3-glycerol phosphate by the tryptophan synthase alpha subunit. The tryptophan biosynthetic genes (ASA1, ASA2) identified in our study were found to enhance DAPG tolerance, based on their GO analysis. In other work, DAPG inhibited primary root growth and stimulated lateral root development in tomato seedlings (Brazelton et al. 2008). Exogenous DAPG applications inhibited the activation of an auxin-inducible $\mathrm{GH} 3$ promoter with a luciferase reporter gene in transgenic tobacco plants, and DAPG was inferred to alter root architecture by inhibiting the auxin-dependent signaling pathway.

Plant sensitivity to DAPG was related to metabolic processes of organic hydroxy compounds (GLX2-1, GLX2-2, GLX2-4, GLX2-5). Glycolate, malate, and lactate are major hydroxyl acids found throughout the plant metabolism pathways (Maurino and Engqvist 2015). Some of them can be found as D- and L-stereoiosmers. In particular, D-lactate is produced as a primary metabolism product in plants during methylglyoxal detoxification, from which a highly reactive cytotoxic compound formed (Mustafiz et al. 2014). Methylglyoxal is produced in plants under conditions of abiotic stress, such as salt, drought, and frost, and this metabolite assists in reducing the

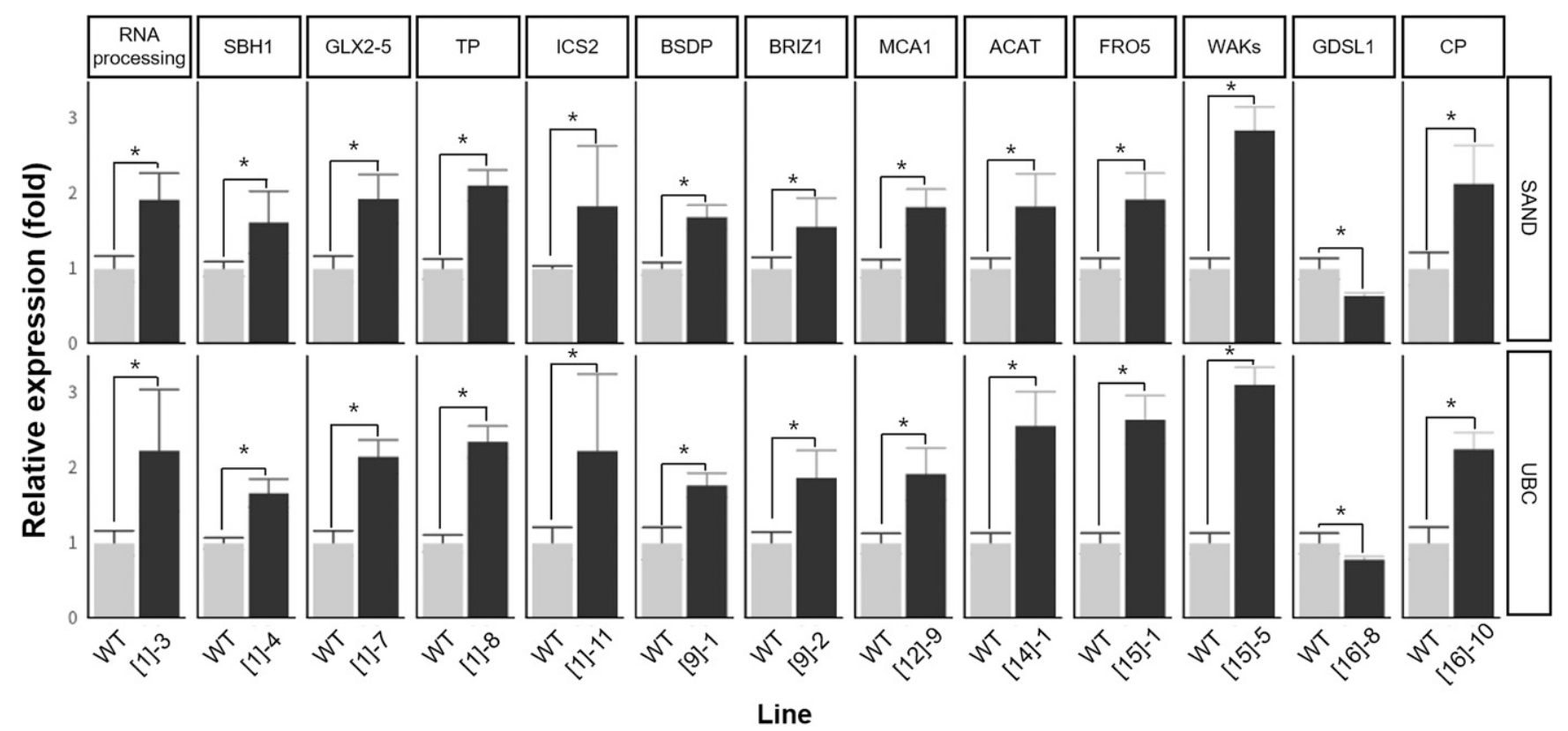

Fig. 3. Relative expression level of the genes that accompanied the inserted loci pSKI015. Total RNA was extracted from 10-day-old plants on Murashige Skoog agar. SYBR Green, quantitative real-time PCR, and normalization by internal standard genes (sand, ubc) were used. Gene expression of the Arabidopsis wild-type Col-2 and the selected lines determined the transcription levels. The experiment was performed using three replications. Error bars represent the standard deviation of the mean. Asterisks indicate a significant difference $(P<0.05)$, according to the Student $t$ test. 
ROS damage (Hoque et al. 2012). D-lactate is metabolized by a cascade of glyoxalases consisting of the enzymes glyoxalase I (GLX1) and glyoxalase II (GLX2) (Mustafiz et al. 2014). Activity to glyoxalase in mitochondrial enhances the cell detoxification function. The mitochondrial electron transport system and oxidoreductase function were also found important in mitigating the toxicity of DAPG in S. cerevisiae (Kwak et al. 2011).

The vacuole in plant cells includes many components, such as protein, sugars, ions, and other secondary metabolites. The vacuolar ATPase is recognized as a key factor in controlling intracellular $\mathrm{pH}$ in vesicles, which is determined by the activity of $\mathrm{H}^{+}$pumps (Dettmer et al. 2006). Plant tolerance of DAPG was increased in the overexpression ([16]-10) line, which had the vacuolar proton transporting V-type ATPase complex (CP). Membrane-associated receptors, including the vacuolar sorting receptors (VSRs) family, mediate selective trafficking to the vacuole of soluble proteins (Kang et al. 2012). The vacuolar cargo trafficking system requires the VSRs to function well (De Marcos Lousa et al. 2012); both the $\mathrm{pH}$ controlling receptor and ligand interaction involves cargo transport to the vacuole (Reguera et al. 2015). Our results suggested the genes involved in vacuole localization of proteins (VSR3, VSR4) were part of the DAPG-tolerance gene network. Both VSR3 and VSR4 are important sorting receptors for storage cargo system in seed and vegetative tissue (Zouhar et al. 2010). The ability of the vacuole to regulate $\mathrm{pH}$ is essential to determining the toxicity of DAPG, which caused to cytosolic acidification in S. cerevisiae (Kwak et al. 2011).

DAPG-producing Pseudomonas spp. are relied upon as primary biocontrol agents in natural disease suppressiveness soils (Kwak and Weller 2013; Valente et al. 2020). Nevertheless, DAPG properties of a plant are not always obvious and several molecular targets are estimated to be involved. Our comprehensive set of results shows that DAPG can be toxic to a plant, whose various mechanisms must operate jointly to prevent DAPG toxicity.

\section{MATERIALS AND METHODS}

Plant material and growing conditions.

Arabidopsis thaliana Col-2 was used as the experimental control. To screen for DAPG-tolerant lines, the activationtagging pools of CS31100 were used, i.e., 208 pools composed of 62,000 homozygote individual lines (the Arabidopsis Biological Resource Center, Columbus, OH, U.S.A.). Seed sterilization was performed by inserting $100 \mathrm{mg}$ of seeds into a $1.7-\mathrm{ml}$ tube and adding $1 \mathrm{ml}$ of $1 \% \mathrm{NaOCl}$, then, vortexing the seed solution for $30 \mathrm{~s}$. Using a pipette, the $\mathrm{NaOCl}$ was drained, and the washing process was carried out as follows. Distilled water (1 ml) was added, then, $30 \mathrm{~s}$ of a vortex mixer and centrifugation were applied to the mixture, with this washing cycle repeated five times. For seed vernalization, the disinfected seeds were stored at $4^{\circ} \mathrm{C}$ for 7 days in the dark. Each plant was grown on $0.7 \%$ MS agar medium (2.1 $\mathrm{g}$ of MS medium, $30 \mathrm{~g}$ of sucrose, $7 \mathrm{~g}$ of phyto agar per liter, $\mathrm{pH} 5.7$ ) at $22^{\circ} \mathrm{C}$ under a $16-\mathrm{h}$ light and 8-h dark photoperiod in a growth chamber (Seyoung Scientific, Bucheon, Korea).

\section{DAPG sensitivity of Arabidopsis thaliana Col-2.}

DAPG (Santa Cruz Biotechnology, Dallas, TX, U.S.A.) was dissolved (100 mM stock solution) in methanol and was placed in a glass bottle wrapped in foil and kept at $-20^{\circ} \mathrm{C}$ to prevent light penetration. Arabidopsis thaliana Col-2 DAPG sensitivity was assessed on the MS agar medium for 10 days. Final DAPG concentrations of $0,20,40,60,80$, and $100 \mu \mathrm{M}$ were amended in MS media, for which 100 to 200 seeds per DAPG concentration ( $n=5$ plates) were used. DAPG-untreated and methanol-only amended plates served as the controls. All the plates were incubated for 10 days under the same growth

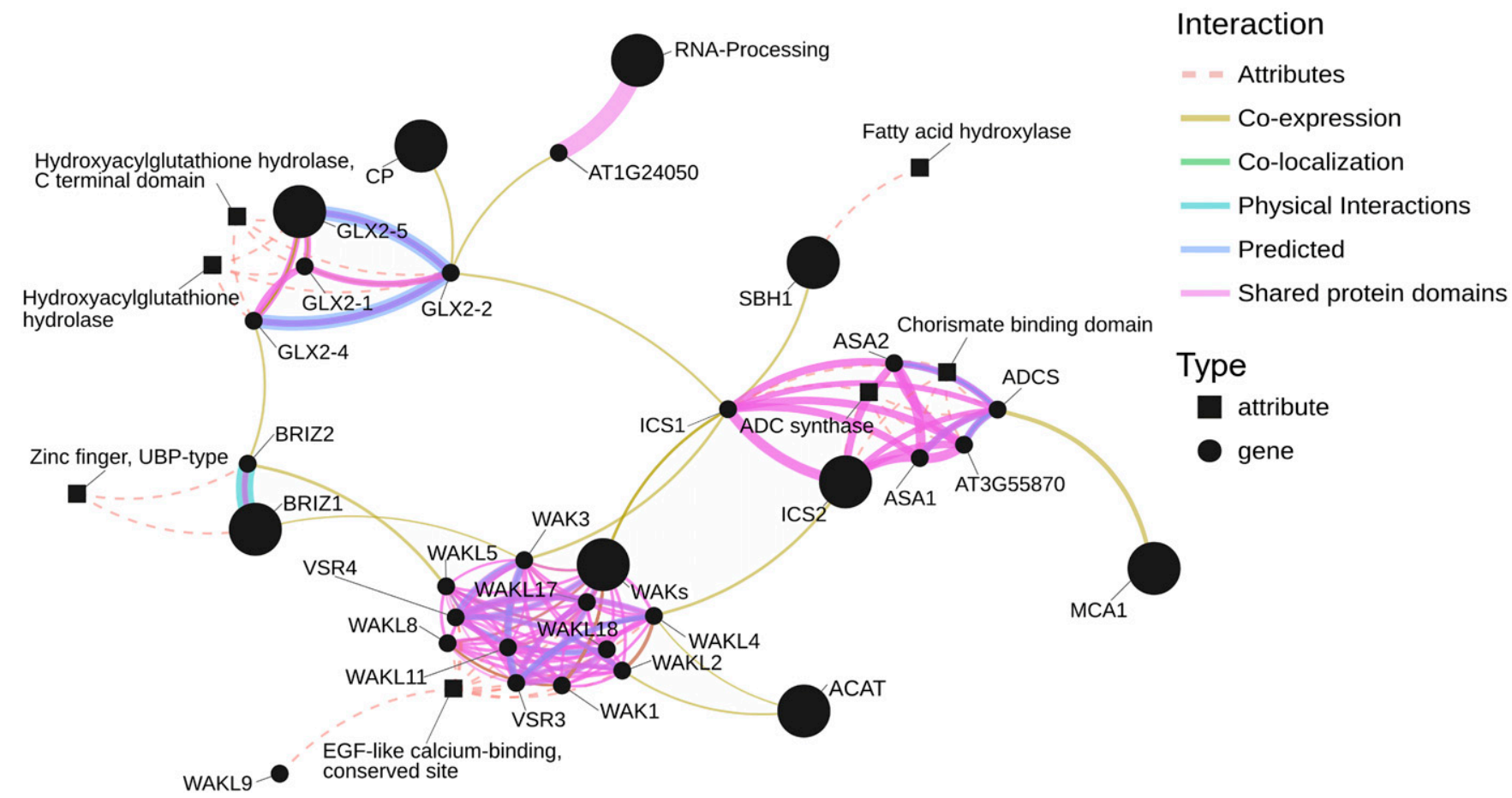

Fig. 4. Network interactions between genes that induce plant tolerance to 2,4-diacetylphloroglucinol in Arabidopsis. Analysis of functional features-InterPro, coexpression, colocalization, physical interactions, predicted protein interactions, and shared protein domains-was performed in the GeneMania system and was visualized using the $\mathrm{R}$ program. Each gene is depicted as a black circle whose attributes are represented as a black square. Larger circles represent the overexpressed genes. Interactions are defined as Interpro (dotted red), coexpression (yellow), colocalization (light green), predicted protein interactions (sea blue), and shared protein domains (pink). 
chamber conditions described above. Seed germination including cotyledon development morphology, and signs of seed rupture were observed for 10 successive days.

\section{Screening for plant DAPG tolerance in the activation-tagging pools.}

In all, 62,000 activation-tagging lines were pooled in 21 groups, with eight to 10 stocks used for the first screening process (Supplementary Table S2). Seed sterilization and vernalization were performed as described above. The pools were screened on MS medium agar, which contained $50 \mu \mathrm{M}$ of DAPG. The plates were incubated in the growth chamber for
10 days. Each plate had 150 to 200 seeds, and the experiment consisted of 10 replications. DAPG-tolerant plants were transferred to bed soil (Hungnong, Pyeongtaek, Korea) and were cultivated for 8 weeks, to harvest the $\mathrm{T}_{4}$ seeds.

For the second screening, the MS medium agar contained $60 \mu \mathrm{M}$ of DAPG. The selected lines were checked individually on a square plate $(125 \times 125 \times 17.8 \mathrm{~mm})$, having six seeds per square with 18 repeats per line. Germination based on seed rupture expressed as the average of the replications. The seeds were cultivated and examined over a 10-day period. The MS media contained 50,60 , or $70 \mu \mathrm{M}$ of DAPG, on which the 16 selected lines underwent final screening.

Table 1. Functional information of genes in the selected 2,4-diacetylphloroglucinol tolerance Arabidopsis lines

\begin{tabular}{|c|c|c|c|c|}
\hline Line (TAIR ID) & Gene & Biological progress & Cellular component & Molecular function \\
\hline [1]-3 (AT1G70220) & $\begin{array}{l}\text { RNA-processing, Lsm } \\
\text { domain-containing protein }\end{array}$ & Unknown & Nucleus & Unknown \\
\hline [1]-4 (AT1G69640) & $\begin{array}{l}\text { Sphingoid base hydroxylase } 1 \\
(S B H 1)\end{array}$ & $\begin{array}{l}\text { Oxidation reduction process, } \\
\text { photomorphogenesis, } \\
\text { sphingoid biosynthetic process }\end{array}$ & $\begin{array}{l}\text { Golgi apparatus, endoplasmic } \\
\text { reticulum, endoplasmic } \\
\text { reticulum membrane, integral } \\
\text { component of membrane }\end{array}$ & $\begin{array}{l}\text { Iron ion binding, oxidoreductase } \\
\text { activity, sphingosine } \\
\text { hydroxylase activity }\end{array}$ \\
\hline [1]-7 (AT2G31350) & Glyoxalase $2-5(G L X 2-5)$ & $\begin{array}{l}\text { Methylglyoxal catabolic process } \\
\text { to D-lactate via } S \text {-lactoyl- } \\
\text { glutathione }\end{array}$ & Chloroplast, mitochondrion & $\begin{array}{l}\text { Iron ion binding, zinc ion } \\
\text { binding }\end{array}$ \\
\hline [1]-8 (AT4G07825) & Transmembrane protein $(T P)$ & Unknown & $\begin{array}{l}\text { Integral component of } \\
\text { membrane, mitocondrion }\end{array}$ & Unknown \\
\hline [1]-11 (AT1G18870) & Isochorismate synthase 2 (ICS2) & $\begin{array}{l}\text { Defense response, phylloquinone } \\
\text { biosynthetic process, salicylic } \\
\text { acid biosynthetic process }\end{array}$ & Chloroplast, plastid & Isochorismate synthase activity \\
\hline [9]-1 (AT3G49800) & $\begin{array}{l}\text { BSD domain-containing protein } \\
\quad(B S D P)\end{array}$ & Unknown & Nucleus & Unknown \\
\hline [9]-2 (AT2G42160) & $\begin{array}{l}\text { BRAP2 ring } \mathrm{ZnF} \text { UBP domain } \\
\text { protein } 1(B R I Z 1)\end{array}$ & Seed germination & Cytoplasm & Ubiquitin transferase \\
\hline [12]-9 (AT4G35920) & $\begin{array}{l}\text { MID1-complementing activity } \\
(M C A 1)\end{array}$ & $\begin{array}{l}\text { Calcium ion transmembrane } \\
\text { transport, calcium ion transport, } \\
\text { carbohydrate homeostasis, } \\
\text { cellular response to mechanical } \\
\text { stimulus, osmosensory } \\
\text { signaling pathway }\end{array}$ & $\begin{array}{l}\text { Integral component of plasma } \\
\text { membrane, nucleus }\end{array}$ & Calcium channel activity \\
\hline [14]-1 (AT3G49190) & $\begin{array}{l}O \text {-acyltransferase (WSD1-like) } \\
\text { family protein }(A C A T)\end{array}$ & $\begin{array}{l}\text { Triglyceride biosynthetic } \\
\text { process }\end{array}$ & Nucleus, plasma membrane & $\begin{array}{l}\text { Diacylglycerol } O \text { - } \\
\text { acyltransferase activity }\end{array}$ \\
\hline [15]-1 (AT5G23990) & $\begin{array}{l}\text { Ferric reduction oxidase } 5 \\
\quad(F R O 5)\end{array}$ & $\begin{array}{l}\text { Ion transport, oxidation- } \\
\text { reduction process }\end{array}$ & $\begin{array}{l}\text { Integral component of } \\
\text { membrane, plasma membrane }\end{array}$ & Ferric chelate reductase activity \\
\hline [15]-5 (AT1G69730) & $\begin{array}{l}\text { Wall-associated kinase family } \\
\text { protein }(W A K s)\end{array}$ & Protein phosphorylation & $\begin{array}{l}\text { Extracellular region, Integral } \\
\text { component of membrane, } \\
\text { plasma membrane }\end{array}$ & $\begin{array}{l}\text { ATP binding, calcium ion } \\
\text { binding, kinase activity, } \\
\text { polysaccharide binding, protein } \\
\text { serine/threonine kinase activity }\end{array}$ \\
\hline [16]-8 (AT1G29670) & $\begin{array}{l}\text { A member of the GDSL } \\
\text { esterase/acylhydrolase family } \\
(G D S L 1)\end{array}$ & Lipid catabolic process & $\begin{array}{l}\text { Apoplast, cell wall, chloroplast } \\
\text { thylakoid, extracellular region, } \\
\text { nucleus }\end{array}$ & Hydrolase activity \\
\hline [16]-10 (AT1G20770) & Coiled-coil protein $(C P)$ & $\begin{array}{l}\text { Vacuolar proton-transporting V- } \\
\text { type ATPase complex } \\
\text { assembly }\end{array}$ & $\begin{array}{l}\text { Extrinsic component of } \\
\text { endoplasmic reticulum } \\
\text { membrane, nucleus }\end{array}$ & Unfolded protein binding \\
\hline
\end{tabular}

Table 2. Gene ontology analysis of the functional network ${ }^{\mathrm{a}}$

\begin{tabular}{lccr}
\hline Function & FDR & Genes in network & Genes in genome \\
\hline Cellular aldehyde metabolic process & 0.000355 & 4 & 21 \\
Thiolester hydrolase activity & 0.005169 & 4 & 3 \\
Integral component of plasma membrane & 0.097404 & 5 & 39 \\
Monocarboxylic acid metabolic process & 0.097404 & 3 & 21 \\
Aromatic amino acid family biosynthetic process & 0.097404 & 3 & 4 \\
Aromatic amino acid family metabolic process & 0.150161 & 4 & 49 \\
Organic hydroxy compound metabolic process & 0.221278 & 2 & 21 \\
Establishment of protein localization to vacuole & 0.538323 & 2 & 21 \\
Tryptophan metabolic process & 0.538323 & 2 & 18 \\
Tryptophan biosynthetic process & 0.538323 & 2 & \\
\hline
\end{tabular}

${ }^{a}$ Each function of genes listed induced an increase in 2,4-diacetylphloroglucinol sensitivity. FDR = false discovery rates. 


\section{Phenotype observation of DAPG tolerance lines.}

The Col-2 and 15 selected lines of Arabidopsis were compared for their phenotype characteristics on $1.2 \%$ MS medium ( $2.1 \mathrm{~g}$ MS medium, $30 \mathrm{~g}$ sucrose, $12 \mathrm{~g}$ phyto agar per liter). The growth chamber conditions were the same as before (discussed above), and the plants grew for 15 days in the vertical direction. Root length and leaf diameter of established seedling were measured using ImageJ software (64-bit java 1.8.0_112). The statistical analysis relied on two-sided Dunnett's multiple comparisons (set at $P<0.05$ ).

\section{TAIL-PCR and sequencing.}

Plant DNA was extracted, using the modified Edward buffer: $200 \mathrm{mM}$ of Tris- $\mathrm{HCl}, \mathrm{pH} 7.5,250 \mathrm{mM}$ of $\mathrm{NaCl}, 25 \mathrm{mM}$ of EDTA, $0.5 \%$ sodium dodecyl sulfate (Edwards et al. 1991). The LB primer was designed using the known sequences of the pSKI015. The characteristics of the three nested primers were that LB1 has a distance of 54 bp to LB0 and LB2 has a distance of 201 bp to LB1 (Supplementary Table S2). As random primers, 21 arbitrary degenerate primers (AD1 approximately 21) were used (Wu et al. 2015). The PCR was performed using KOD-FX-Neo (Toyobo, Osaka, Japan) and Top DNA polymerase (Bioneer, Daejeon, Korea). The PCR reaction mixture conditions can be found in Supplementary Table S3. The primary TAIL-PCR program went as follows: $4^{\circ} \mathrm{C}$ for $2 \mathrm{~min}, 93^{\circ} \mathrm{C}$ for $1 \mathrm{~min}, 95^{\circ} \mathrm{C}$ for $1 \mathrm{~min}$, then four cycles at $94^{\circ} \mathrm{C}$ for $30 \mathrm{~s}$, $62^{\circ} \mathrm{C}$ for $1 \mathrm{~min}, 72^{\circ} \mathrm{C} 4 \mathrm{~min}$, followed by $94^{\circ} \mathrm{C}$ for $30 \mathrm{~s}, 25^{\circ} \mathrm{C}$ for $3 \mathrm{~min}$, ramp up for $4 \mathrm{~min}\left(0.2^{\circ} \mathrm{C}\right.$ per second up to $\left.72^{\circ} \mathrm{C}\right)$, $72^{\circ} \mathrm{C}$ for $2 \mathrm{~min} 30 \mathrm{~s}, 14$ cycles at $94^{\circ} \mathrm{C}$ for $10 \mathrm{~s}, 68^{\circ} \mathrm{C}$ for $1 \mathrm{~min}$, $72^{\circ} \mathrm{C}$ for $3 \mathrm{~min}, 94^{\circ} \mathrm{C}$ for $10 \mathrm{~s}, 68^{\circ} \mathrm{C}$ for $1 \mathrm{~min}, 72^{\circ} \mathrm{C}$ for $3 \mathrm{~min}$, $94^{\circ} \mathrm{C}$ for $10 \mathrm{~s}, 44^{\circ} \mathrm{C}$ for $1 \mathrm{~min}, 72^{\circ} \mathrm{C}$ for $3 \mathrm{~min}$. All the samples were incubated at $72^{\circ} \mathrm{C}$ for $10 \mathrm{~min}$ and were then held at $4^{\circ} \mathrm{C}$. The secondary TAIL-PCR program was performed as follows: $4^{\circ} \mathrm{C}$ for $2 \mathrm{~min}, 11$ cycles at $94^{\circ} \mathrm{C}$ for $10 \mathrm{~s}, 64^{\circ} \mathrm{C}$ for $1 \mathrm{~min}, 72^{\circ} \mathrm{C}$ for $3 \mathrm{~min}, 94^{\circ} \mathrm{C}$ for $10 \mathrm{~s}, 64^{\circ} \mathrm{C}$ for $1 \mathrm{~min}, 72^{\circ} \mathrm{C}$ for $3 \mathrm{~min}, 94^{\circ} \mathrm{C}$ for $10 \mathrm{~s}, 44^{\circ} \mathrm{C}$ for $1 \mathrm{~min}, 72^{\circ} \mathrm{C}$ for $3 \mathrm{~min}$, and the final extension was performed at $72^{\circ} \mathrm{C}$ for $10 \mathrm{~min}$ and held at $4^{\circ} \mathrm{C}$. The tertiary TAIL-PCR program consisted of $4^{\circ} \mathrm{C}$ for $2 \mathrm{~min}$, then 19 cycles at $94^{\circ} \mathrm{C}$ for $10 \mathrm{~s}, 44^{\circ} \mathrm{C}$ for $1 \mathrm{~min}$, and $72^{\circ} \mathrm{C}$ for $2 \mathrm{~min}$. The PCR products were verified by gel electrophoresis (1.0\% agarose), and the DNA fragments were extracted from the gel using the Expin Gel SV (GeneAll, Seoul, Korea). For the sequencing, a TAIL-PCR template was used with LB2 and amplified AD primers.

\section{RNA extraction, RT, and qRT-PCR.}

Arabidopsis $\left(\mathrm{T}_{5}\right)$ activation-tagging lines and Col-2 plants were grown on MS medium for 10 days and were homogenized (using liquid nitrogen). Their RNA was extracted from homogenized samples with the RiboEx kit (GeneAll) and was then stored at $-80^{\circ} \mathrm{C}$. The cDNA was synthesized using ReverTra Ace- $\alpha$ - (Toyobo), for which $2 \mu \mathrm{g}$ of total RNA was used per sample for cDNA synthesis as follows: $4 \mu \mathrm{l}$ of $5 \times \mathrm{RT}$ buffer, $2 \mu \mathrm{l}$ of dNTP mixture (10 mM each), $1 \mu$ l of RNase inhibitor $(10 \mathrm{U} / \mu \mathrm{l}), 1 \mu \mathrm{l}$ of Oligo (dT) $20(10 \mathrm{pmol} / \mu \mathrm{l})$, and $1 \mu \mathrm{l}$ of ReverTra Ace, with RNase-free $\mathrm{H}_{2} \mathrm{O}$ added to attain the 20$\mu$ final volume. The PCR machine was set for $20 \mathrm{~min}$ at $42^{\circ} \mathrm{C}$; after the synthesis process, the RNA polymerase was inactivated by a heat treatment $\left(99^{\circ} \mathrm{C}\right.$ for $\left.5 \mathrm{~min}\right)$. The qRT-PCR was performed using SYBR Green Real-Time PCR master mix (Toyobo). The reaction volume $(20 \mu \mathrm{l})$ comprised $1 \mu \mathrm{l}$ of 50 fold diluted cDNA, $10 \mu \mathrm{l}$ of SYBR Green, $1 \mu \mathrm{l}$ of each forward and reverse primer, and $7 \mu$ of distilled water (Supplementary Table S4). Both $u b c$ and sand were employed as housekeeping reference genes (Czechowski et al. 2005). The qRT-PCR was carried out in a thermocycler (Bio-Rad, Hercules, CA, U.S.A.). Its cycle conditions were as follow: $95^{\circ} \mathrm{C}$ for $1 \mathrm{~min}$, then 44 cycles at $95^{\circ} \mathrm{C}$ for $15 \mathrm{~s}, 56^{\circ} \mathrm{C}$ for $15 \mathrm{~s}$, and $72^{\circ} \mathrm{C}$ for $30 \mathrm{~s}$, followed by $95^{\circ} \mathrm{C}$ for $10 \mathrm{~s}$ and $55^{\circ} \mathrm{C}$ for $5 \mathrm{~s}$. This experiment had three replications per gene. Relative gene expression levels were calculated by the cycle threshold method and, so, were quantified with respect to the internal control gene.

\section{Mapping the insertion loci and chromosome.}

Genes conferring plant tolerance to DAPG were searched for in The Arabidopsis Information Resource (TAIR) database. Their respective identification number was used to identify their locus on the Arabidopsis genome and place of insertion, for which the chromosome map tool (TAIR database) was used. To insert the flanking gene into the genome, the sequence was used and identified by TAIL-PCR amplicon sequence information; it was confirmed to be the start-end point and direction of pSKI015.

\section{Network and GO.}

Network and GO analyses were conducted to categorize the functional groups of DAPG tolerance-related genes. The functional network within the genes was grouped by GeneMANIA, a prediction tool for network weights based upon the relevance among the query genes (Montojo et al. 2014). Only overexpressed genes were identified as query values. The detailed options were confirmed by biological process-based network, and the maximum resultant gene value was 21 and the maximum resultant attributes adjusted to 15 . Network data were obtained using default setting for attributes, coexpression, colocalization, genetic interactions, physical interactions, predicted, and shared protein domains. The raw data were used to visualize the network in the $\mathrm{R}$ computing platform. GO terms predicted via the functional enrichment analysis were obtained from the GeneMANIA.

\section{AUTHOR-RECOMMENDED INTERNET RESOURCES}

GeneMANIA online network: https://genemania.org

TAIR website: https://www.arabidopsis.org

\section{LITERATURE CITED}

Bartel, B. 1997. Auxin biosynthesis. Annu. Rev. Plant Physiol. Plant Mol. Biol. 48:51-66.

Brazelton, J. N., Pfeufer, E. E., Sweat, T. A., Gardener, B. B., and Coenen, C. 2008. 2,4-diacetylphloroglucinol alters plant root development. Mol. Plant-Microbe Interact. 21:1349-1358.

Czechowski, T., Stitt, M., Altmann, T., Udvardi, M. K., and Scheible, W. R. 2005. Genome-wide identification and testing of superior reference genes for transcript normalization in Arabidopsis. Plant Physiol. 139:5-17.

De Marcos Lousa, C., Gershlick, D. C., and Denecke, J. 2012. Mechanisms and concepts paving the way towards a complete transport cycle of plant vacuolar sorting receptors. Plant Cell 24:1714-1732.

Dettmer, J., Hong-Hermesdorf, A., Stierhof, Y. D., and Schumacher, K. 2006. Vacuolar $\mathrm{H}^{+}$-ATPase activity is required for endocytic and secretory trafficking in Arabidopsis. Plant Cell 18:715-730.

Edwards, K., Johnstone, C., and Thompson, C. 1991. A simple and rapid method for the preparation of plant genomic DNA for PCR analysis. Nucleic Acids Res. 19:1349.

Haas, D., and Keel, C. 2003. Regulation of antibiotic production in rootcolonizing Peudomonas spp. and relevance for biological control of plant disease. Annu. Rev. Phytopathol. 41:117-153.

Hoque, T. S., Uraji, M., Ye, W., Hossain, M. A., Nakamura, Y., and Murata, Y. 2012. Methylglyoxal-induced stomatal closure accompanied by peroxidase-mediated ROS production in Arabidopsis. J. Plant Physiol. 169:979-986.

Kang, H., Kim, S. Y., Song, K., Sohn, E. J., Lee, Y., Lee, D. W., HaraNishimura, I., and Hwang, I. 2012. Trafficking of vacuolar proteins: The crucial role of Arabidopsis vacuolar protein sorting 29 in recycling vacuolar sorting receptor. Plant Cell 24:5058-5073.

Keel, C., Schnider, U., Maurhofer, M., Voisard, C., Laville, J., Burger, L., Wirthner, P., Haas, D., and Défago, G. 1992. Suppression of root diseases 
by Pseudomonas fluorescens CHA0: Importance of the bacterial secondary metabolite 2,4-diacetylphloroglucinol. Mol. Plant-Microbe Interact. 5:4-13.

Kotchoni, S. O., Kuhns, C., Ditzer, A., Kirch, H. H., and Bartels, D. 2006. Over-expression of different aldehyde dehydrogenase genes in Arabidopsis thaliana confers tolerance to abiotic stress and protects plants against lipid peroxidation and oxidative stress. Plant Cell Environ. 29: 1033-1048.

Kwak, Y.-S., Han, S., Thomashow, L. S., Rice, J. T., Paulitz, T. C., Kim, D., and Weller, D. M. 2011. Saccharomyces cerevisiae genome-wide mutant screen for sensitivity to 2,4-diacetylphloroglucinol, an antibiotic produced by Pseudomonas fluorescens. Appl. Environ. Microbiol. 77: 1770-1776.

Kwak, Y. S., and Weller, D. M. 2013. Take-all of wheat and natural disease suppression: A review. Plant Pathol. J. 29:125-135.

LoPachin, R. M., and Gavin, T. 2014. Molecular mechanisms of aldehyde toxicity: A chemical perspective. Chem. Res. Toxicol. 27: 1081-1091.

Maurhofer, M., Keel, C., Haas, D., and Défago, G. 1995. Influence of plant species on disease suppression by Pseudomonas fluorescens strain CHAO with enhanced antibiotic production. Plant Pathol. 44:40-50.

Maurino, V. G., and Engqvist, M. K. 2015. 2-Hydroxy acids in plant metabolism. Arabidopsis Book 13:e0182.

Montojo, J., Zuberi, K., Rodriguez, H., Bader, G. D., and Morris, Q. 2014. GeneMANIA: Fast gene network construction and function prediction for Cytoscape. F1000 Res. 3:153.

Mustafiz, A., Ghosh, A., Tripathi, A. K., Kaur, C., Ganguly, A. K., Bhavesh, N. S., Tripathi, J. K., Pareek, A., Sopory, S. K., and Singla-Pareek, S. L. 2014. A unique $\mathrm{Ni}^{2+}$-dependent and methylglyoxal-inducible rice glyoxalase I possesses a single active site and functions in abiotic stress response. Plant J. 78:951-963.

Phillips, D. A., Fox, T. C., King, M. D., Bhuvaneswari, T. V., and Teuber, L. R. 2004. Microbial products trigger amino acid exudation from plant roots. Plant Physiol. 136:2887-2894.

Raaijmakers, J. M., and Weller, D. M. 2001. Exploiting genotypic diversity of 2,4-diacetylphloroglucinol-producing Pseudomonas spp.: Characterization of superior root-colonizing P. fluorescens strain Q8r1-96. Appl. Environ. Microbiol. 67:2545-2554.

Raaijmakers, J. M., and Weller, D. M. 1998. Natural plant protection by 2,4diacetylphloroglucinol-producing Pseudomonas spp. in take-all decline soils. Mol. Plant-Microbe Interact. 11:144-152.

Reguera, M., Bassil, E., Tajima, H., Wimmer, M., Chanoca, A., Otegui, M. S., Paris, N., and Blumwald, E. 2015. pH regulation by NHX-type antiporters is required for receptor-mediated protein trafficking to the vacuole in Arabidopsis. Plant Cell 27:1200-1217.
Schulz, R., Vargiu, A. V., Ruggerone, P., and Kleinekathöfer, U. 2011. Role of water during the extrusion of substrates by the efflux transporter AcrB. J. Phys. Chem. B 115:8278-8287.

Tani, H., Chen, X., Nurmberg, P., Grant, J. J., SantaMaria, M., Chini, A., Gilroy, E., Birch, P. R., and Loake, G. J. 2004. Activation tagging in plants: A tool for gene discovery. Funct. Integr. Genomics 4:258-266.

Troppens, D. M., Dmitriev, R. I., Papkovsky, D. B., O'Gara, F., and Morrissey, J. P. 2013. Genome-wide investigation of cellular targets and mode of action of the antifungal bacterial metabolite 2,4-diacetylphloroglucinol in Saccharomyces cerevisiae. FEMS Yeast Res. 13:322-334.

Tzin, V., and Galili, G. 2010. New insights into the shikimate and aromatic amino acids biosynthesis pathways in plants. Mol. Plant 3:956-972

Valente, J., Gerin, F., Le Gouis, J., Moënne-Loccoz, Y., and Prigent-Combaret, C. 2020. Ancient wheat varieties have a higher ability to interact with plant growth-promoting rhizobacteria. Plant Cell Environ. 43:246-260.

Vogt, R. A., Rahman, S., and Crespo-Hernández, C. E. 2010. Structureactivity relationships in nitro-aromatic compounds. Page 214-240 in: Practical Aspects of Computational Chemistry. J. Leszczynsk and M. K. Shukla, eds. Springer, New York.

Wang, Y., Ohara, Y., Nakayashiki, H., Tosa, Y., and Mayama, S. 2005. Microarray analysis of the gene expression profile induced by the endophytic plant growth-promoting rhizobacteria, Pseudomonas fluorescens FPT9601T5 in Arabidopsis. Mol. Plant-Microbe Interact. 18:385-396.

Weigel, D., Ahn, J. H., Blázquez, M. A., Borevitz, J. O., Christensen, S. K., Fankhauser, C., Ferrándiz, C., Kardailsky, I., Malancharuvil, E. J., Neff, M. M., Nguyen, J. T., Sato, S., Wang, Z.-Y., Xia, Y., Dixon, R. A., Harrison, M. J., Lamb, C. J., Yanofsky, M. F., and Chory, J. 2000. Activation tagging in Arabidopsis. Plant Physiol. 122:1003-1014.

Weller, D. M., Landa, B. B., Mavrodi, O. V., Schroeder, K. L., De La Fuente, L., Blouin Bankhead, S., Allende Molar, R., Bonsall, R. F., Mavrodi, D. V., and Thomashow, L. S. 2007. Role of 2,4diacetylphloroglucinol-producing fluorescent Pseudomonas spp. in the defense of plant roots. Plant Biol Stuttg 9:4-20.

Wu, L., Di, D. W., Zhang, D., Song, B., Luo, P., and Guo, G. Q. 2015. Frequent problems and their resolutions by using thermal asymmetric interlaced PCR (TAIL-PCR) to clone genes in Arabidopsis T-DNA tagged mutants. Biotechnol. Biotechnol. Equip. 29:260-267.

Zhang, L. H., Jia, B., Zhuo, R. Y., Liu, J. L., Pan, H. Y., Baldwin, T. C., and Zhang, S. H. 2012. An acyl-acyl carrier protein thioesterase gene isolated from wintersweet (Chimonanthus praecox), CPFATB, enhances drought tolerance in transgenic tobacco (Nicotiana tobaccum). Plant Mol. Biol. Report. 30:433-442.

Zouhar, J., Muñoz, A., and Rojo, E. 2010. Functional specialization within the vacuolar sorting receptor family: VSR1, VSR3 and VSR4 sort vacuolar storage cargo in seeds and vegetative tissues. Plant J. 64:577-588. 